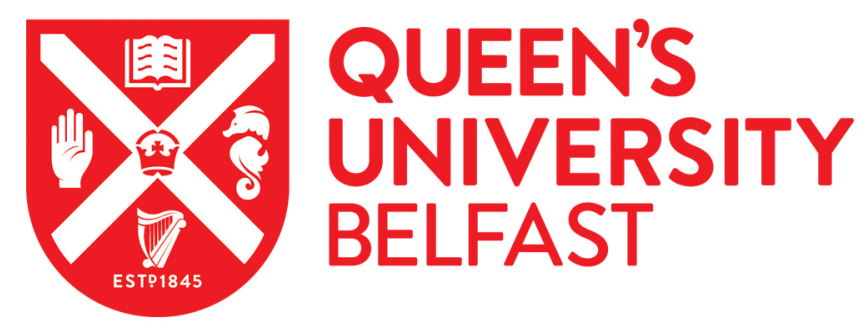

\title{
The analysis of dissolved inorganic carbon in liquid using a microfluidic conductivity sensor with membrane separation of $\mathrm{CO} 2$
}

Tweedie, M., Sun, D., Gajula, D. R., Ward, B., \& Maguire, P. (2020). The analysis of dissolved inorganic carbon in liquid using a microfluidic conductivity sensor with membrane separation of CO2. Microfluidics and Nanofluidics, 24(37). https://doi.org/10.1007/s10404-020-02339-1

Published in:

Microfluidics and Nanofluidics

Document Version:

Publisher's PDF, also known as Version of record

Queen's University Belfast - Research Portal:

Link to publication record in Queen's University Belfast Research Portal

Publisher rights

Copyright 2020 the authors.

This is an open access article published under a Creative Commons Attribution License (https://creativecommons.org/licenses/by/4.0/), which permits unrestricted use, distribution and reproduction in any medium, provided the author and source are cited.

\section{General rights}

Copyright for the publications made accessible via the Queen's University Belfast Research Portal is retained by the author(s) and / or other copyright owners and it is a condition of accessing these publications that users recognise and abide by the legal requirements associated with these rights.

Take down policy

The Research Portal is Queen's institutional repository that provides access to Queen's research output. Every effort has been made to ensure that content in the Research Portal does not infringe any person's rights, or applicable UK laws. If you discover content in the Research Portal that you believe breaches copyright or violates any law, please contact openaccess@qub.ac.uk. 


\title{
The analysis of dissolved inorganic carbon in liquid using a microfluidic conductivity sensor with membrane separation of $\mathrm{CO}_{2}$
}

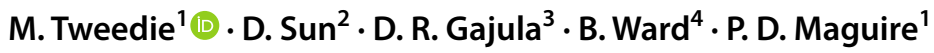

Received: 29 October 2019 / Accepted: 2 April 2020

(c) The Author(s) 2020

\begin{abstract}
Autonomous continuous analysis of oceanic dissolved inorganic carbon (DIC) concentration with depth is of great significance with regard to ocean acidification and climate change. However, miniaturisation of in situ analysis systems is hampered by the size, cost and power requirements of traditional optical instrumentation. Here, we report a low-cost microfluidic alternative based on $\mathrm{CO}_{2}$ separation and conductance measurements that could lead to integrated lab-on-chip systems for ocean float deployment, or for moored or autonomous surface vehicle applications. Conductimetric determination of concentration, in the seawater range of $1000-3000 \mu \mathrm{mol} \mathrm{kg}{ }^{-1}$, has been achieved using a microfluidic thin-film electrode conductivity cell and a membrane-based gas exchange cell. Sample acidification released $\mathrm{CO}_{2}$ through the membrane, reacting in a $\mathrm{NaOH}$ carrier, later drawn through a sub- $\mu \mathrm{L}$ conductivity cell, for impedance versus time measurements. Precision values (relative standard deviations) were $\sim 0.2 \%$ for peak height measurements at $2000 \mu \mathrm{mol} \mathrm{kg}^{-1}$. Comparable precision values of $\sim 0.25 \%$ were obtained using a C4D electrophoresis headstage with similar measurement volume. The required total sample and reagent volumes were $\sim 500 \mu \mathrm{L}$ for the low volume planar membrane gas exchange cell. In contrast, previous conductivitybased DIC analysis systems required total volumes between 5000 and 10,000 $\mu \mathrm{L}$. Long membrane tubes and macroscopic wire electrodes were avoided by incorporating a planar membrane (PDMS) in the gas exchange cell, and by sputter deposition of Ti/Au electrodes directly onto a thermoplastic (PMMA) manifold. Future performance improvements will address membrane chemical and mechanical stability, further volume reduction, and component integration into a single manifold.
\end{abstract}

Keywords Dissolved inorganic carbon $\cdot \mathrm{CO}_{2} \cdot$ Conductivity $\cdot$ Impedance $\cdot$ Microfluidics $\cdot$ PDMS membrane

\section{Introduction}

Atmospheric carbon dioxide concentration has increased significantly due to human activity and is a primary contributor to global warming. The ocean is a major sink for

M. Tweedie

m.tweedie@ulster.ac.uk

$\triangle$ P. D. Maguire

pd.maguire@ulster.ac.uk

$1 \quad$ Nanotechnology and Integrated BioEngineering Centre (NIBEC), Ulster University, Jordanstown, Newtownabbey BT37 0QB, UK

2 School of Mechanical and Aerospace Engineering, Queen's University, Belfast BT9 5AH, UK

3 Department of Electrical and Computer Engineering, Clemson University, Clemson, SC 29634, USA

4 AirSea Laboratory, Ryan Institute and School of Physics, National University of Ireland, Galway, Ireland anthropogenic $\mathrm{CO}_{2}$, mitigating the effects of atmospheric emissions with the $\mathrm{CO}_{2}$ uptake causing changes to ocean chemistry (Sabine et al. 2004). However, the ability of the oceans to continue absorption at historic levels is uncertain, particularly since, in the first instance, $\mathrm{CO}_{2}$ solubility decreases with rising temperature. To permit modelling of $\mathrm{CO}_{2}$ atmosphere:ocean interchange and $\mathrm{CO}_{2}$ ocean absorption with climate change, depth profile measurements are required continuously from across the world's oceans. While the importance of ocean chemistry is recognised, our ability to measure ocean variables with sufficient resolution and accuracy is severely restricted due to a lack of analysis systems capable of low-cost and widespread deployment.

The state of the oceanic $\mathrm{CO}_{2}$ system can be determined by measuring at least two of four variables, namely, $\mathrm{CO}_{2}$ partial pressure $\left(\mathrm{pCO}_{2}\right), \mathrm{pH}$, the total alkalinity $\left(A_{\mathrm{T}}\right)$, and the dissolved inorganic carbon (DIC) (Millero 2007). The latter consists of $\mathrm{CO}_{2}$ dissolved in seawater, mainly as bicarbonate, $\mathrm{HCO}_{3}{ }^{-}$, and carbonate $\mathrm{CO}_{3}{ }^{2-}$ ions, with small amounts of 
carbonic acid, $\mathrm{H}_{2} \mathrm{CO}_{3}$, and $\mathrm{CO}_{2}$ molecules. The standard concentration of dissolved $\mathrm{CO}_{2}$ in seawater at sea level is around $1900 \mu \mathrm{mol} \mathrm{kg}{ }^{-1}$, rising to $>2400 \mu \mathrm{mol} \mathrm{kg}^{-1}$ at depth (Wang et al. 2013), assuming current values of $\mathrm{pH}(\sim 8.2)$ and atmospheric $\mathrm{CO}_{2}$ content (400 ppm) (Dlugokencky and Tans 2019). The relevant ions cannot be detected directly against the large background of seawater ions, which are mostly from dissolved $\mathrm{NaCl}$ and $\mathrm{MgSO}_{4}$, with typically $35 \mathrm{~g}$ of salts per litre. Therefore, the DIC ions must be first extracted from the seawater by conversion to $\mathrm{CO}_{2}$ gas molecules, for transfer through a gas permeable membrane into a receiving channel for measurement. The addition of excess acid to seawater, reducing the $\mathrm{pH}$ to $\leq 4.5$, releases DIC as gaseous $\mathrm{CO}_{2}$ into the aqueous phase for membrane separation. The receiving channel may comprise vacuum, inert gas, or reactive solution, where the DIC amount transferred can be measured by a variety of methods.

At present, $\mathrm{CO}_{2}$ measurements are typically carried out by coulometry using large-volume sensors on research ships, according to Standard Operating Protocols (Dickson et al. 2007). Although both $\mathrm{pCO}_{2}$ and $\mathrm{pH}$ are very sensitive to temperature and pressure, they can be measured away from sampling depths under carefully controlled conditions, and while microfluidic miniaturisation approaches for in situ surface measurements are currently being developed, complementary autonomous measurements of DIC or $A_{\mathrm{T}}$ would be preferred (Rérolle et al. 2018; Clarke et al. 2017). Given the technical challenges, however, such approaches have yet to be realised (Byrne 2014).

Non-conductimetric measurement methods for DIC determination have been reported, using e.g. gas chromatography (Hansen et al. 2013), and membrane inlet mass spectroscopy (Tortell 2005; Guéguen and Tortell 2008; Bell et al. 2011; Freije-Carrelo et al. 2018). Optical methods include nondispersive IR (Kaltin et al. 2005; Fassbender et al. 2015; Bass et al. 2012a, b) and spectrophotometry (Nakano et al. 2006; Wang et al. 2007, 2013; Liu et al. 2013). The partial pressure of $\mathrm{CO}_{2},\left(\mathrm{pCO}_{2}\right)$, has also been measured by spectrophotometry, on an autonomous moored submersible instrument (DeGrandpre et al. 1995). Recently, a compact LED-based spectrophotometric instrument for in situ measurement has been reported, capable of achieving DIC precision of $\pm 2.5 \mu \mathrm{mol} \mathrm{kg}{ }^{-1}$ with a $700 \mu \mathrm{L}$ sample cell and total sample and reagent volumes of $9000 \mu \mathrm{L}$ per sample (Wang et al. 2015). However, these are all large systems and unfortunately do not offer an obvious route to miniaturisation.

Coulometry is the recommended standard operating procedure for bench DIC determination (Dickson et al. 2007). However, a flow injection method (Hall and Aller 1992) based on a conductimetric technique, with microfluidic channels on either side of a planar gas exchange membrane, offers greater opportunity for miniaturisation. Here, the $\mathrm{CO}_{2}$ is collected in an alkaline receiving solution, typically
$\mathrm{NaOH}$. Provided the $\mathrm{pH}$ of this solution is sufficiently low, the added $\mathrm{CO}_{2}$ aq. is converted to $\mathrm{CO}_{3}{ }^{2-}$ through reaction with $\mathrm{OH}^{-}$and due to the lower mobility of the former, the fluid conductivity is reduced in direct proportion to the added $\mathrm{CO}_{2}$ concentration. The use of conductimetric techniques for determining DIC concentration has also been reported more recently (Sayles and Eck 2009; Bresnahan and Martz 2018). Fluid conductance/impedance techniques are rarely considered for high-resolution chemical analysis as accuracy and precision are generally poorer than with colorimetric or optical techniques. This is exacerbated with small sample volumes when deployed in a microfluidic structure. Nevertheless, in this case, because of the high potential for microfluidic system miniaturisation, we examine the applicability of these techniques to DIC measurements.

Sayles and Eck suggest that the optimum reference receiver solution concentration for $\sim 2 \mathrm{mM}$ DIC measurement is $\sim 7 \mathrm{mM} \mathrm{NaOH}$, but Hall and Aller originally achieved acceptable results for $10 \mathrm{mM} \mathrm{NaOH}$. The receiving solution conductivity is $\sim 170 \mathrm{mS} \mathrm{m}^{-1}$ for $7 \mathrm{mM}$, and $220 \mathrm{mS} \mathrm{m}^{-1}$ for $10 \mathrm{mM} \mathrm{NaOH}$. Sayles and Eck used a $\sim 150 \mu \mathrm{L}$ conductivity cell containing Pt wires and a $1000 \mu \mathrm{L}$ sample cell, with a silicone inner tube containing $\mathrm{NaOH}$ which acts as the membrane receiving cell (330 $\mu \mathrm{L})$ (Sayles and Eck 2009). The analysis time per sample was $\sim 1 \mathrm{~h}$ and required sample and reagent volumes (acid, $\mathrm{NaOH}$ ) of $2500 \mu \mathrm{L}$ and $8500 \mu \mathrm{L}$, respectively. In laboratory and field tests, they obtained precision values of $\pm 2.2 \mu \mathrm{mol} \mathrm{kg}-1$ and $\pm 3.6 \mu \mathrm{mol} \mathrm{kg} \mathrm{kg}^{-1}$, equivalent to relative standard deviations (RSD) of $\pm 0.11 \%$ and $\pm 0.18 \%$, respectively. For comparison, laboratory DIC coulometric calibration measurements using standard operating procedures, have cited precision values of \pm 1.5 to $\pm 2.0 \mu \mathrm{mol} \mathrm{kg}{ }^{-1}$ (Dickson et al. 2007).

Plant et al. (2009) also used a conductimetric approach to detect ammonium in marine environments. The sample and receiving channels $(100 \mu \mathrm{L} / 50 \mu \mathrm{L})$ were formed in two thermoplastic blocks which sandwiched a thin PTFE membrane and the conductivity cell $(50 \mu \mathrm{L})$ comprised two macroscopic plates. A detection limit of $0.2 \mu \mathrm{M}$ was achieved with minimum error levels of $2.5 \%$ (above $3 \mu \mathrm{M}$ ). The accuracy was limited by the transfer of ions across the semi-porous PTFE membrane. The analysis time was $\sim 7 \mathrm{~min}$ and required sample and reagent volumes of $1650 \mu \mathrm{L}$ and $3800 \mu \mathrm{L}$, respectively.

Other conductimetric cell designs include concentric metal tubes (Henríquez et al. 2014) and contactless arrangements involving insulated wire pairs (Hoherčáková and Opekar 2005) or a capillary electrophoresis (C4D) headstage (Bresnahan and Martz 2018). In the latter work, diffusion time, membrane type and surface area to cell volume was investigated for sample volumes up to $300 \mu \mathrm{L}$. Although the headstage unit was relatively large, each measurement point required a very small volume of liquid 
$(<5 \mu \mathrm{L})$ and with signal averaging, a precision of $\sim 0.1 \%$ was achieved.

One possible application of a miniaturized DIC measurement approach is integration onto profiling float platforms for open ocean monitoring of the upper $2000 \mathrm{~m}$ (Bresnahan et al. 2017). DIC insensitivity to pressure and temperature would allow for sample collection at different depths for subsequent analysis elsewhere. This could include use at a preset park depth, or even on-ship or in a laboratory, depending on the degree of miniaturisation achievable for the whole system. This would require detailed design of reagent storage volumes, on-chip multiple sample storage, and pumps and valves dimensions.

The Argo network is a well-known ocean profiling system currently consisting of $>3000$ globally distributed autonomous ocean profile floats, providing continuous depth profiling of salinity and temperature (Roemmich et al. 2009). These are intended to drift in the open ocean for at least 5 years, early failures notwithstanding, and are programmed to profile the upper $2 \mathrm{~km}$ of ocean every 5-10 days with the data then transmitted to satellite. Typically, these floats, for diameters greater than $170 \mathrm{~mm}$, can offer a sensor payload capability of at least $1.5 \mathrm{~kg}$, while currently available sensors vary in volume from about $0.2 \mathrm{~L}$ to over $3 \mathrm{~L}$. On this platform, DIC sensors would need to operate long term with total reagent volumes preferably less than $1 \mathrm{~L}$. At 100 samples per profile, reagent limits per sample are, therefore, $<100 \mu \mathrm{L}$ and with sample flushing between measurements, this may be lowered considerably. Overall, this small cell volume requirement represents a significant challenge for both fabrication and detection accuracy and precision. On a less restrictive platform, of course, such as for instruments tethered to moored buoys, or in autonomous surface vehicles, where volume is not so restricted, the DIC sensors reported here will be more easily implemented.

Other constraints on DIC sensors on oceanic probes relate to the long-term and harsh environment operation, where robust chemically resilient device bonding is essential with additional features, e.g. multiple layers, mixed materials and multi-channel structures, not normally considered in mainstream microfluidics which is focussed primarily on biomedical applications. Recently, though, we demonstrated long-term PDMS membrane bonding within a thermoplastic manifold (Tweedie et al. 2019) as well high-pressure resilient thermoplastic bonding for multi-layer and multi-channel devices (Sun et al. 2015).

In this work, we investigate direct contact conductivity cells with active volumes between 0.5 and $2.0 \mu \mathrm{L}$ for DIC detection in the seawater range $1900-2400 \mu \mathrm{mol} \mathrm{kg}{ }^{-1}$. For these volumes, the use of macroscopic wires or plates as electrodes is not feasible and instead, we developed a thinfilm metallisation process onto PMMA using a sputtered thin film of gold $(<200 \mathrm{~nm})$ on top of a $10 \mathrm{~nm}$ adhesion promoting inter layer of sputtered $\mathrm{Ti}$.

\section{Materials and experimental methods}

\subsection{Fabrication}

Various components were fabricated in NIBEC (Nanotechnology and Integrated Bio-Engineering Centre) to facilitate this research. First, a planar Au electrode microfluidic conductivity cell was required for electrical measurements. Second, a membrane exchange diffusion cell, with a gas permeable membrane, was needed for transferring liberated $\mathrm{CO}_{2}$ from the acidified sample solution into $\mathrm{NaOH}$ receiving solution for DIC determination. The sample solution was prepared at various molarities directly related to the known DIC range in seawater, from $\mathrm{NaHCO}_{3}$ stock solution (Sigma Aldrich). Third, an asymmetric $\mathrm{Y}$ meter was required for accurate dynamic metering of acid into sample solution, for automated DIC measurements.

\subsubsection{Conductivity cell}

Metal electrodes were fabricated by RF sputtering of a Ti adhesion layer $(<10 \mathrm{~nm})$, followed by DC magnetron sputtering of an Au layer $(\sim 200 \mathrm{~nm})$ through a shadow mask onto flat PMMA substrates to form the electrode pattern. This was then bonded to a second PMMA manifold, wherein the fluid channel had been formed, using $\mathrm{CHCl}_{3}$ solvent vapour-assisted thermocompression bonding at $80{ }^{\circ} \mathrm{C}$ in vacuum (Sun et al. 2015). Electrode integrity was tested for resilience against $\mathrm{NaOH}(9 \mathrm{mM}, \mathrm{pH} 12)$ corrosion over several weeks. The electrode cell construction is illustrated in Fig. 1a. Microfluidic channels were milled with an equal height and width of $0.5 \mathrm{~mm}$ and the electrode gap was varied from 0.25 to $2 \mathrm{~mm}$, giving an active measurement volume range of $0.5-2.0 \mu \mathrm{L}$. The cells were completed with the attachment of Nanoport fluidic connections using epoxy and sealed with silicone, for subsequent immersion in a temperature-controlled $\left( \pm 0.05{ }^{\circ} \mathrm{C}\right)$ water bath. Green dye flow through a DI water filled sensor cell is shown in Fig. 1b, where some excess solution is required to fully remove previous sample contents.

\subsubsection{Membrane exchange diffusion cell}

To operate at reduced system volumes, the use of silicone tubes as previously reported may not be practical for gas exchange diffusion cells (Nakano et al. 2006; Wang et al. 2013, 2015; Liu et al. 2013; Bresnahan and Martz 2018). Here, though, we used a membrane exchange diffusion cell consisting of two PMMA substrates with patterned sample 


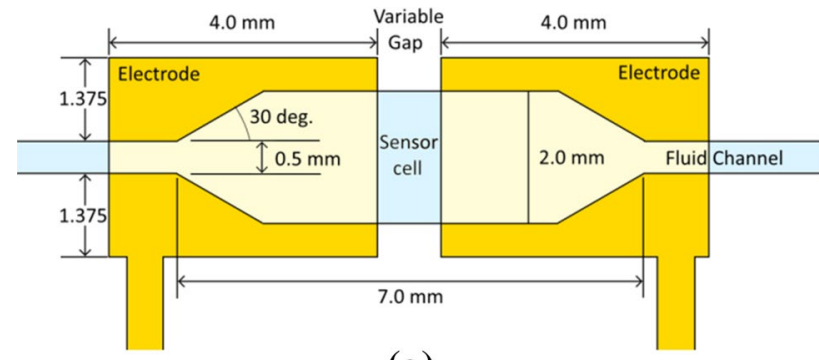

(a)

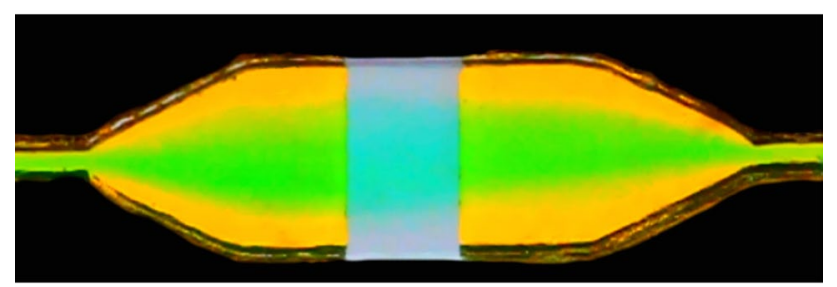

(b)

Fig. 1 a Electrode pair and sensor cell schematic. b Photo of $\mathrm{Au} / \mathrm{Ti}$ electrode pair and sensor cell with green dye input, through DI water prefill. A modest excess flow volume is required to totally clear the cell of previous sample contents. Dimensions are as in (a)

and receiving chambers along with associated microfluidic channels and fluid connectors, separated by a thin membrane sheet. Recently, we investigated a range of membrane sheet materials to determine optimum $\mathrm{CO}_{2}$ exchange versus unwanted ion conductivity and from this it was clear that PDMS performance is far superior to other materials (Tweedie et al. 2019), especially compared to PTFE membranes that have been previously reported (Plant et al. 2009). Here, we have used a series of chambers of $1 \mathrm{~mm}^{2}$ crosssection and variable length from 12 to $300 \mathrm{~mm}$, CNC micromachined on separate substrates with a $50 \mu \mathrm{m}$ PDMS film membrane (Goodfellow Cambridge Ltd.) fixed between the two opposing sides, see plan view, Fig. 2.

\subsubsection{Y meter fabrication}

For dynamic DIC mixing, $\mathrm{HCl}$ acid is injected into the $\mathrm{NaHCO}_{3}$ flow stream, rather than by bulk pre-mixing. For this, we used an asymmetric Y-junction reagent meter, fabricated in-house by $\mathrm{CO}_{2}$ laser etching of PMMA (Fig. 3a) and sealed by solvent $\left(\mathrm{CHCl}_{3}\right)$ vapour-assisted bonding ( $\mathrm{Sun}$ et al. 2015), as in the example in Fig. 3b. The laser used was a 25 W VLS2.30 model from Universal Laser Systems. The $\mathrm{NaHCO}_{3}$ input channel width was $\sim 400 \mu \mathrm{m}$, and depth was $\sim 298 \mu \mathrm{m}$, written in raster mode at $35 \%$ power $(8.75 \mathrm{~W})$, and $0.3 \mathrm{~m} / \mathrm{s}$. The base of the channel was approximately flat over a width of $\sim 100 \mu \mathrm{m}$. A set of vectors, written at powers of $12.5,15$ and $20 \%$ levels, and speeds of $0.3 \mathrm{~m} / \mathrm{s}$, was used to produce narrow $\mathrm{HCl}$ input channels, giving $\mathrm{Y}$

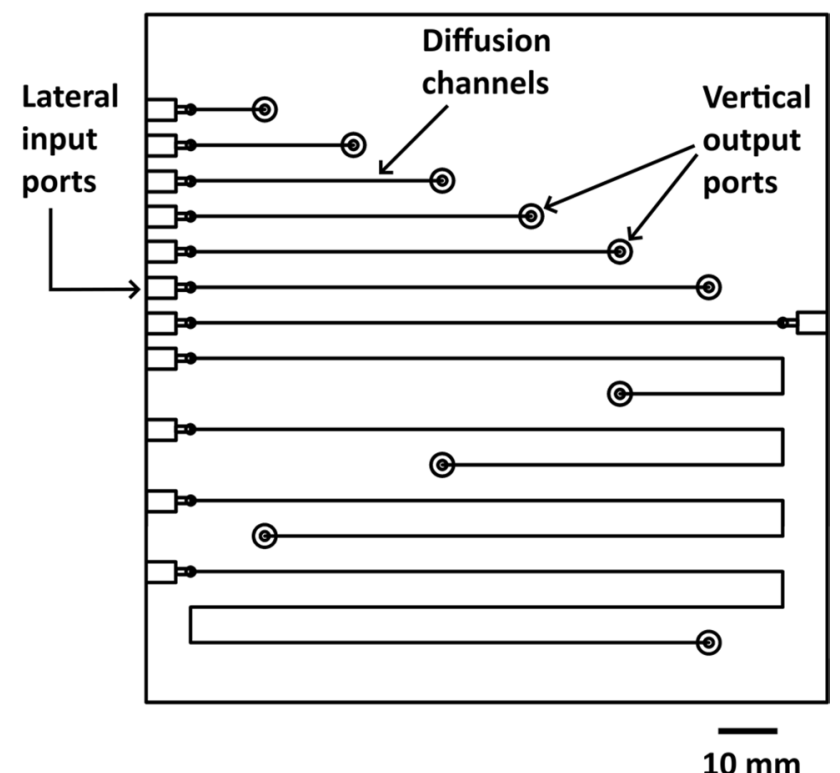

Fig. 2 Plan view drawing of multiple membrane exchange diffusion cells, where the PDMS membrane is sealed between opposite halves

meters of meter ratios $\sim 14: 1,10: 1$ and $6: 1$. These devices have been separately described, along with various long channel restrictors, for controlling metering ratios (Tweedie et al. 2020). The dimensions of the vectored channel for the 6:1 Y meter are $\sim 130 \mu \mathrm{m}$ top width, and depth $\sim 230 \mu \mathrm{m}$, with a roughly $\mathrm{V}$-shaped cross-sectional profile, Fig. $3 \mathrm{~b}$. This device was used in these tests, with $0.1 \mathrm{M} \mathrm{HCl}$ input, effectively diluted down $6 \mathrm{X}$ by the $\mathrm{Y}$ meter to $\sim 16.7 \mathrm{mM}$, which is sufficient excess to liberate all $\mathrm{CO}_{2}$ from the $2 \mathrm{mM}$ $\mathrm{NaHCO}_{3}$ source.

\subsection{Experimental methods}

A Solartron SI 1260 Impedance/Gain-phase analyser was used, with SI 1287 or SI 1294 impedance interfaces, to measure the fluid impedance and phase angle at data acquisition rates from 1 per minute to a maximum 1 per $5 \mathrm{~s}(0.2 \mathrm{~Hz})$. The excitation frequency was chosen to minimise the absolute value of phase angle, so that readings had a minimum capacitive component and maximum resistive component. Impedance measurement software was either SMaRT, which, for impedance terms, outputs the magnitude, $\mid \mathrm{Zl}$, or ZView, which recorded both the real and imaginary components, Z' and Z', where Z' equates to the resistance. Cell calibration was undertaken with standard $\mathrm{KCl}$ solutions (Hanna Instruments).

For initial sensor testing, $|\mathrm{Z}|$ was measured for $9 \mathrm{mM}$ $\mathrm{NaOH}$ over several hours to assess thermal drift, and sensor noise. Then two solutions with a conductivity difference of $1 \%\left(139.9 \mathrm{mS} \mathrm{m}^{-1}\right.$ and $\left.141.3 \mathrm{mS} \mathrm{m}^{-1}\right)$ were used for repetitively switched sampling. An Elveflow AF1 P1600 


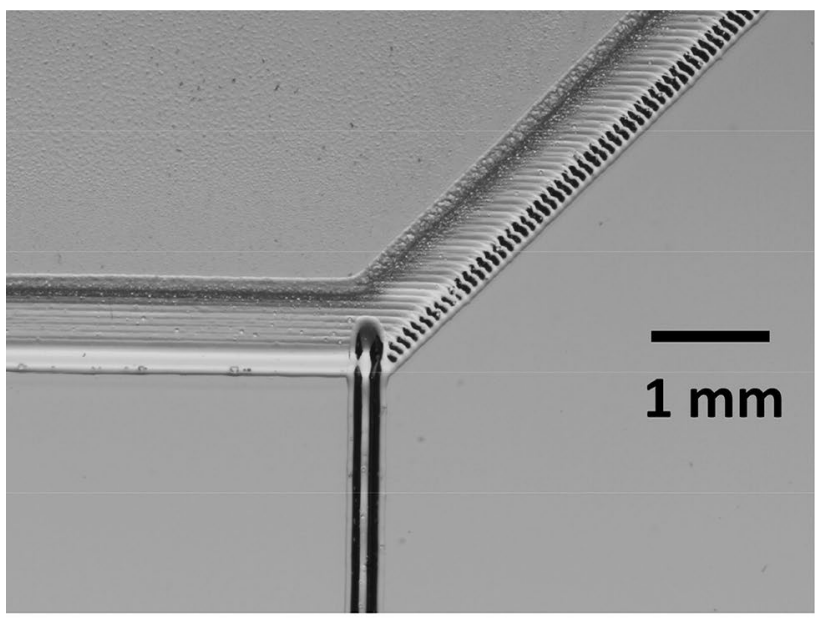

(a)

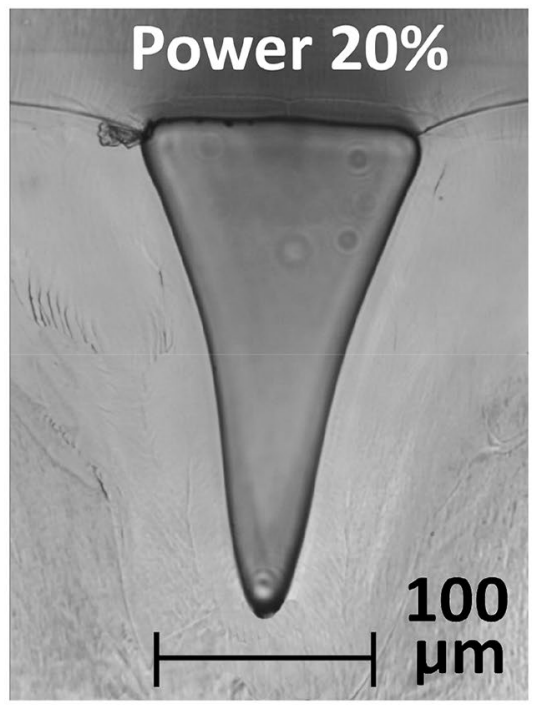

(b)

Fig. 3 a Asymmetric Y meter example, as engraved by $\mathrm{CO}_{2}$ laser. The thin vector engraved channel is vertical in the image plane, while the remainder is engraved by raster scan from left to right. Raster engraved at $8.75 \mathrm{~W}$, vector at $5 \mathrm{~W}$, both at $0.3 \mathrm{~m} / \mathrm{s}$. The rastered channels are wider here, than in practice, for better visibility. Actual bonded devices used a reduced $\mathrm{NaHCO}_{3}$ and output channel width, compared to this example, of $\sim 400 \mu \mathrm{m}$. b Example of vector engraved channel cross-section in PMMA, post bond. Engraving power $5 \mathrm{~W}$, at speed of $0.3 \mathrm{~m} / \mathrm{s}$

pump, with manually operated valves, was used to pressurise a bottle of each solution in turn and the solution bottles and sensor cell were held in a Heraeus oven at $27.5^{\circ} \mathrm{C}$.

Before the asymmetric Y meter had been fabricated, DIC solutions were made via bulk premix of acid and sample. Here, $\mathrm{CO}_{2}$ loaded solutions were prepared by mixing preset amounts of $0.1 \mathrm{M} \mathrm{NaHCO}_{3}$ (Sigma Aldrich UK) with degassed DI water, creating a DIC content from 1.0 to $3.0 \mathrm{mM}$, depending on dilution ratio. $\mathrm{HCl}(0.1 \mathrm{M})$ was then mixed with this in a 5\% $v / v$ (acid:sample) ratio, either in a sealed vessel, or in a syringe. The acid was effectively diluted to $\sim 5.0 \mathrm{mM}$, of sufficient excess to liberate the maximum of $3.0 \mathrm{mM} \mathrm{CO}_{2}$ from the DIC solution. After 20-25 min reaction time, the sample was injected at the diffusion test cell input, under positive pressure. For initial diffusion cell comparisons and calibration testing, the receiver $(\mathrm{NaOH})$ chamber was purged with fresh solution using a programmable syringe pump (Aladdin) before the $\mathrm{CO}_{2}$ sample was added to the sample chamber. A diffusion time of $20 \mathrm{~min}$ allowed sufficient exchange of $\mathrm{CO}_{2}$ from sample to receiver chamber across the membrane. The $\mathrm{CO}_{2}$-loaded $\mathrm{NaOH}$ solution was then pumped through the Au sensor cells, for impedance measurement, and the cycle repeated as desired. Calibrations were performed for 1.0-3.0 mM DIC using a $\sim 200 \mu \mathrm{L}$ receiving chamber and a total sample volume of $1 \mathrm{~mL}$.

Subsequently, once a calibration had been achieved using bulk pre-mixing of acid and sample, experiments proceeded to use dynamic acid and sample mixing via the fabricated asymmetric Y meter, with measurements using the Au sensor. For comparison, a contactless capillary electrophoresis headstage and controller (eDAQ ET125/ ER225 C4D) was also used (Bresnahan and Martz 2018). The fluid conductivity is determined within a capillary tube using external electrodes driven at high frequency $(1.2 \mathrm{MHz})$ and voltage $(200 \mathrm{~V})$, acquiring data points at a rate of $1 \mathrm{~Hz}$. The active eDAQ C4D measurement volume between electrodes was $\sim 2 \mu \mathrm{L}$.

Exchange cell volumes were reduced to $100 \mu \mathrm{L}$, with $\mathrm{NaOH}$ reagent volumes for the elution curve of 350-600 $\mu \mathrm{L}$, depending on flow rate. Cetoni NeMeSys Low Pressure syringe pumps, with QMix control software, were used to draw fluid through both sides of the gas exchange cell in sequence. The DIC solution was drawn through at a fixed rate $\left(7.5-8.5 \mu \mathrm{L} \mathrm{s}^{-1}\right)$, followed by $15 \mathrm{~min}$ diffusion. $\mathrm{NaOH}$ was then drawn through at a fixed rate 1.5-1.7 $\mu \mathrm{L} \mathrm{s}^{-1}$. Each elution peak was therefore at least $200 \mathrm{~s}$. A small number of samples were drawn through at $12 \mu \mathrm{L} \mathrm{s}^{-1}$ to evaluate the impact of high flow rates. A temperature stabilised water bath, using an NE4-D/CT Clifton digital temperature-controlled heater and stirrer, in combination with a DC1-300 Clifton chiller, was used to compensate for long-term thermal drifts. The stated temperature sensitivity, after stabilisation, is $\pm 0.05^{\circ} \mathrm{C}$. The C4D sensor head was immersed in a silicone oil bath (Xiameter PMX200 silicone fluid, 20cS) within the water bath, while the Au sensor microfluidics were immersed directly in the water bath, which was set at $25^{\circ} \mathrm{C}$. The reagent bags were not temperature stabilised. A schematic diagram of the negative pressure experimental setup is shown in Fig. 4. 


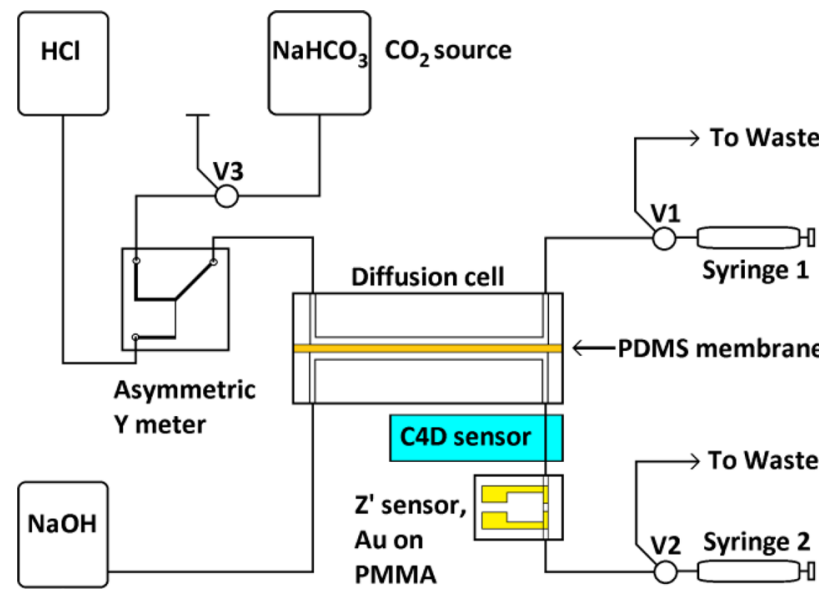

Fig. 4 Schematic diagram of negative pressure system for $Z^{\prime}$ and C4D measurements of DIC. The temperature stabilised water bath is omitted for clarity. The three port valves are V1-V3

\section{Results and discussion}

Optimum test conditions for impedance measurements were determined initially using a $9.1 \mathrm{mM}\left(\sim 200 \mathrm{mS} \mathrm{m}^{-1}\right) \mathrm{NaOH}$ solution. The phase angle reduced to a minimum absolute value at $63.096 \mathrm{kHz}$, for $0.5 \mathrm{~mm}$ gap electrodes, and at $50-100 \mathrm{kHz}$ for $0.9 \mathrm{~mm}$ gap electrodes. The optimum signal-to-noise ratio (SNR) occurred at a software selected level of $100 \mathrm{mV}$ rms. Continuous IZI impedance measurements were acquired at $60 \mathrm{~s}$ intervals over $7 \mathrm{~h}$, as shown in Fig. 5. The expected temperature dependence of ionic liquid conductivity is $\sim 2 \% /{ }^{\circ} \mathrm{C}$, while the $\mid \mathrm{ZI}$ drift in Fig. 5 is $\sim 0.95 \%$, as would be produced by a temperature drift of $0.475{ }^{\circ} \mathrm{C}$. A fourth order polynomial was fitted to the data to subtract the background drift, for the purpose of evaluating

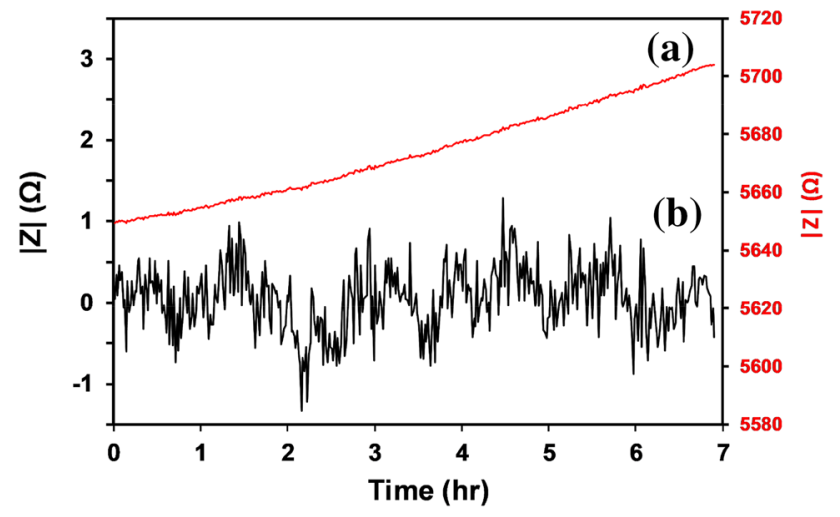

Fig. 5 Time variation in $|\mathrm{Z}|$ for $9.1 \mathrm{mM} \mathrm{NaOH}$ solution $\left(\sim 200 \mathrm{mS} \mathrm{m}^{-1}\right)$ for a raw data, and b drift-corrected data, using a fourth order polynomial fit. The drift-corrected data gives an rms noise of $0.39 \Omega$ the rms noise, as shown in Fig. 5. The rms noise for $9.1 \mathrm{mM}$ $\left(\sim 200 \mathrm{mS} \mathrm{m}^{-1}\right) \mathrm{NaOH}$ solution is $0.39 \Omega$. The estimated cell constant is $\sim 1140 \mathrm{~m}^{-1}$.

The repeatability of the measurement was examined by cyclic switching between two $\mathrm{KCl}$ solutions with a nominal conductance difference of $1 \%$. Background drift correction, similar to that in Fig. 5, was applied, see Fig. 6. The average impedance was $8522 \Omega$, and average $\mid \mathrm{ZI}$ was calculated from 25 data points sampled, just prior to each switching event. The $\mid \mathrm{ZI}$ time series is shown in Fig. $6(63,096 \mathrm{~Hz}$, $100 \mathrm{mV}$ rms input, and $0 \mathrm{~V} \mathrm{DC}$ ), where the average $\mid \mathrm{ZI}$ is $\sim 62.5 \Omega$ and the estimated rms noise is $\sim 0.71 \Omega$. The rms sensor noise is at a very low level compared to the background $(\sim 0.008 \%)$, but the precision for DIC measurement will depend firstly on the $|\mathrm{Z}|$ signal change produced by the maximum $\mathrm{CO}_{2}$ level to be detected. The rms noise divided by the maximum signal, expressed as a percentage, can indicate the best theoretical precision achievable for the sensor noise component alone, ignoring other noise contributors for now. Known full system spectrophotometric and conductimetric field precision values (RSD) lie in the range of 0.14-0.18\% (Wang et al 2013, 2015; Sayles and Eck 2009), equating to $2.8-3.6 \mu \mathrm{mol} \mathrm{kg}{ }^{-1}$, for an average DIC level of $2000 \mu \mathrm{mol} \mathrm{kg}{ }^{-1}$. The final system precision will be worse than the sensor precision because of factors such as measurement fluctuations from e.g. membrane relaxations, residual temperature drifts, and long-term reagent changes.

For DIC calibration testing, under acid:sample DIC premix conditions, $200 \mu \mathrm{L}$ sample and receive chambers were used with a $50 \mu \mathrm{m}$ PDMS membrane. Diffusion tests were carried out for $2000 \mu \mathrm{M}$ DIC and $0.9 \mathrm{~mm}$ electrode gap, at $100 \mathrm{kHz}$ and $100 \mathrm{mV}$ rms. Each elution peak was $\sim 120 \mathrm{~s}$ with peak heights of $\sim 6600 \Omega$, after background subtraction. The measured rms noise was $1.05 \Omega$, giving a SNR of $\sim 6285: 1$. Although the measured SNR suggests a possible theoretical precision of $0.016 \%$, the observed rms peak variation, after background subtraction, in Fig. 7 is

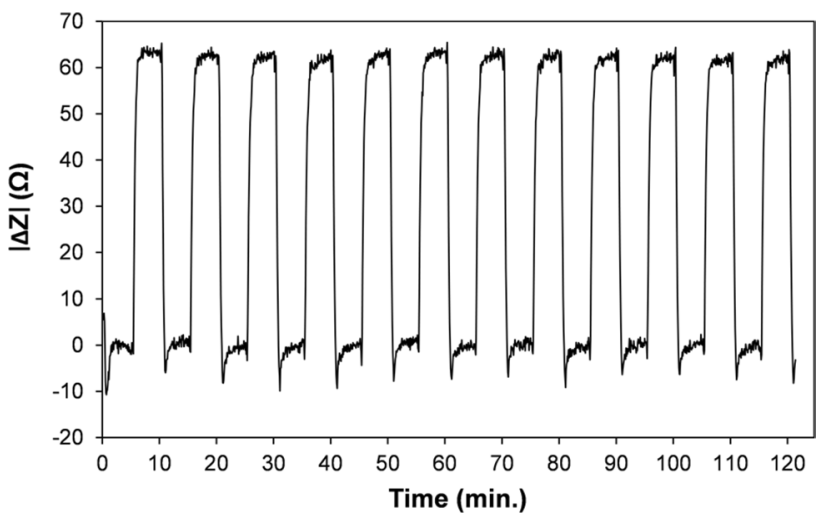

Fig. 6 Repeatability data for switching between two fluids with a conductivity difference of $1 \%\left(139.9 \mathrm{mS} \mathrm{m}^{-1}\right.$ and $\left.141.3 \mathrm{mS} \mathrm{m}^{-1}\right)$ 


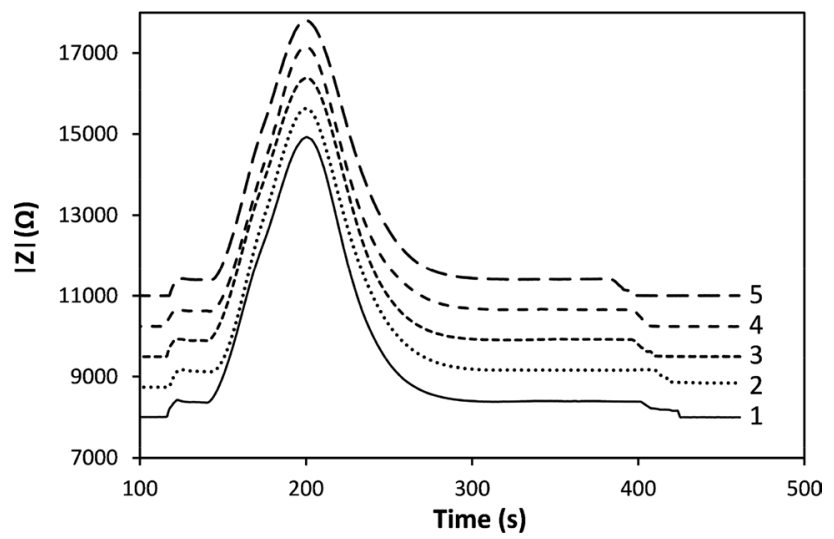

Fig. $7 \mathrm{IZI}$ for repeat samples of $2 \mathrm{mM} \mathrm{TCO} \mathrm{Tsing}_{2}$ a $0.9 \mathrm{~mm}$ electrode gap, $100 \mathrm{mV} \mathrm{rms,} 0 \mathrm{~V} \mathrm{DC}, 100 \mathrm{kHz}$, with 20 min diffusion

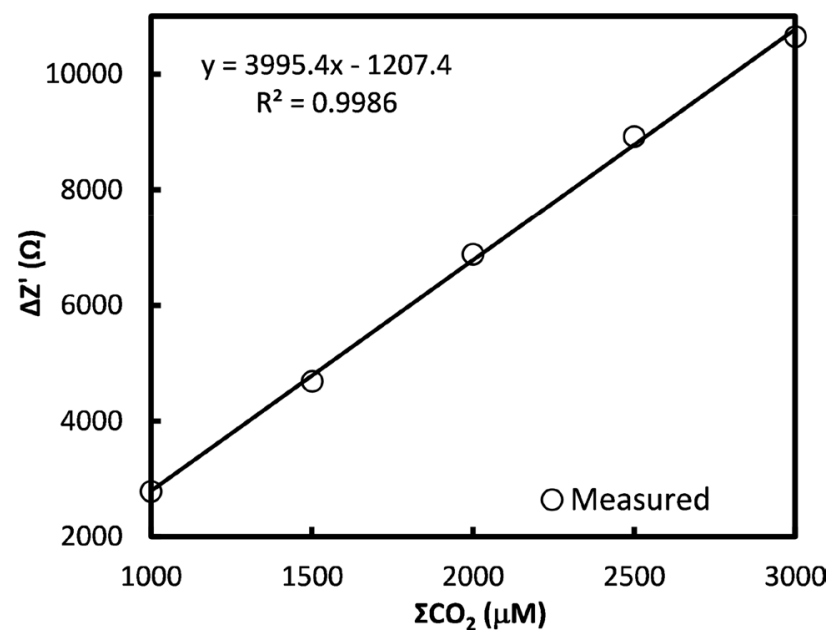

Fig. 8 DIC calibration for $200 \mu \mathrm{L}$ sample and receive chambers and $20 \mathrm{~min}$ diffusion (0.9 mm gap, $100 \mathrm{mV} \mathrm{rms}, 0 \mathrm{~V} \mathrm{DC}, 100 \mathrm{kHz})$

actually $\sim 0.7 \%$, as a result of uncorrected background ripples, which are suspected to be partly due to fluctuations in the flexible PDMS membrane, from residual flow perturbations. Furthermore, these initial experiments were not highly temperature stabilised, so greater variability would be expected from this factor also.

The calibration curve for $1000-3000 \mu \mathrm{M}$ DIC is given in Fig. 8 and is observed to be linear $\left(R^{2}>0.99\right)$ over this range. The RSD (not shown) is less than $0.8 \%$.

Under dynamic DIC mixing conditions, using acid injection into the DIC loaded flow stream, elution peak sequences were obtained for Au sensor direct contact $(50 \mathrm{kHz}, 100 \mathrm{mV}$ rms, $0 \mathrm{~V} \mathrm{DC}$ ) and C4D conductivity cells, examples of which are shown in Fig. 9. These data were captured for $9.1 \mathrm{mM} \mathrm{NaOH}$ solution, as used previously.

The $\mathrm{NaOH}$ solution was then changed to $7.0 \mathrm{mM}$ (Sayles and Eck 2009), for optimising the conductivity

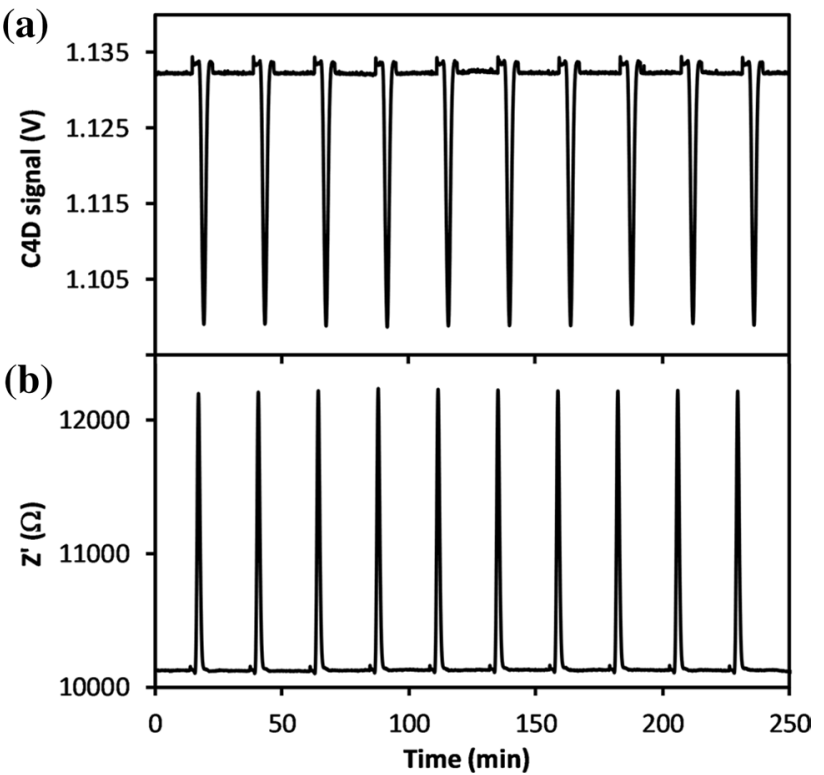

Fig. 9 a C4D peak sequence sample with $2000 \mu \mathrm{M}$ DIC solution, a $100 \mu \mathrm{L}$ channel and diffusion time of $15 \mathrm{~min}, \mathbf{b} \mathrm{Z}$ ' peak sequence sample under same conditions. The conductivity cell interelectrode gap was $0.9 \mathrm{~mm}$, and $9.1 \mathrm{mM} \mathrm{NaOH}$ was used

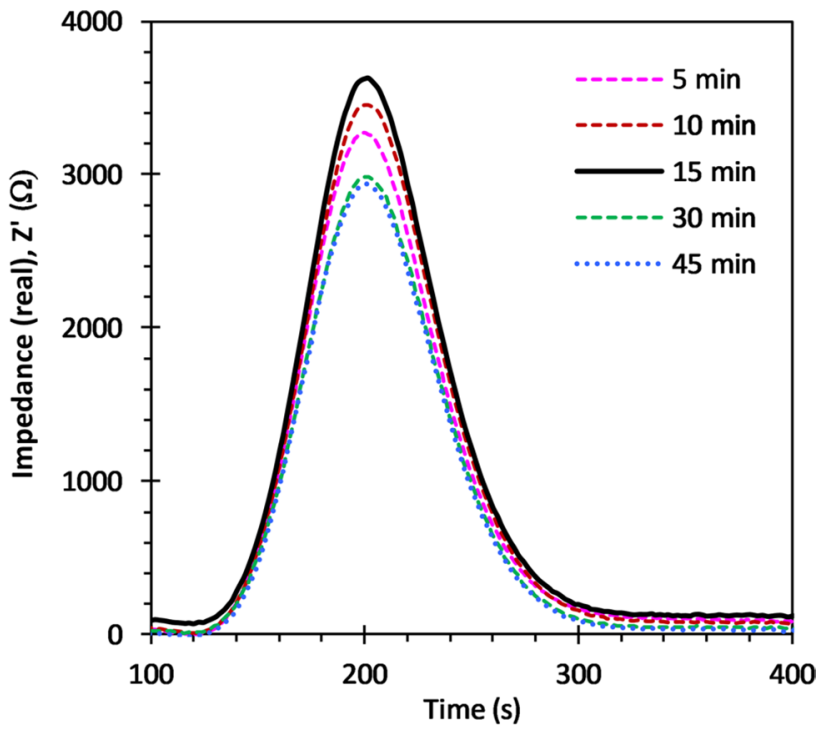

Fig. 10 Elution peak characteristics for diffusion times up to $45 \mathrm{~min}$, with $0.9 \mathrm{~mm}$ interelectrode gap, and $7 \mathrm{mM} \mathrm{NaOH}$ receiving solution

for best response. The elution characteristics were tested for various membrane diffusion periods from 5 min until 45 min, Fig. 10, and under low and high flow conditions, Fig. 12. The $\mid \Delta Z$ 'l signals were found to increase substantially from $\sim 2100$ to $\sim 3500 \Omega$, with the change from 9.1 to $7.0 \mathrm{mM} \mathrm{NaOH}$, for the same $15 \mathrm{~min}$ diffusion hold time, and flow characteristics throughout. 
Measurement precision was determined from peak sequences taken over many hours with peak heights and area values extracted using an automatic procedure. First, a quadratic Savitzky-Golay smoothing function was applied to the raw signal and using the first and second SavitzkyGolay derivatives, the start, end and peak positions were obtained, Fig. 11 (Gorry 1991). The baseline represents the conductivity of the $\mathrm{NaOH}$ blank, the average value of which was determined using a $50 \mathrm{~s}$ window on either side of each peak, offset from the peak start and end points by $25 \mathrm{~s}$, and subsequently subtracted from the signal. The ultimate achievable precision values, obtained from baseline SNR, are $\sim 0.10 \%$ and $\sim 0.15 \%$, for $Z^{\prime}$ and CFD, respectively. However, the uncertainty in $Z$ ' and C4D signal peak height and area values, obtained from the long sequence measurements, depends on diffusion time and flow rate, as well as membrane instabilities, and residual temperature drifts.

The peak height and its RSD variation with diffusion time is shown in Fig. 12. The former increases with diffusion time up to $15 \mathrm{~min}$ and then falls thereafter, while the RSD variation is almost the inverse, decreasing to a minimum of $<0.2 \%$ for 30 min diffusion. The DIC mass transfer ratio, obtained from integrating the area under the curve, follows the same trend as peak height with a maximum value of $80 \%$ occurring after 15 min diffusion, falling to $~ 65 \%$ after $45 \mathrm{~min}$. Under low flow conditions, the average pulse width varied from 210 to $228 \mathrm{~s}$. This equates to a reagent volume of $\sim 350 \mu \mathrm{L}$, for a sample input volume of $100 \mu \mathrm{L}$. Increasing the flow rate by a factor of $7.5-12 \mu \mathrm{L} \mathrm{s}^{-1}$, results in higher RSD with reduced peak heights and mass transfer ratios of around $70 \%$ or less. The reagent volume increased

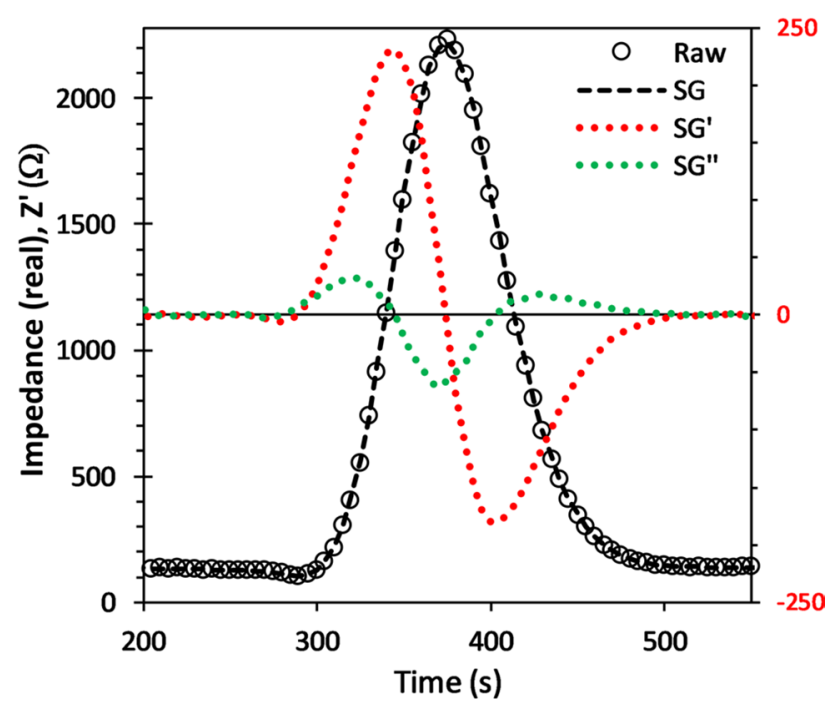

Fig. 11 Elution peak raw data to which a Savitzky-Golay smoothing function is applied (SG). The generated 1st (SG') and 2nd (SG') derivatives are used to determine start and end points, along with peak position

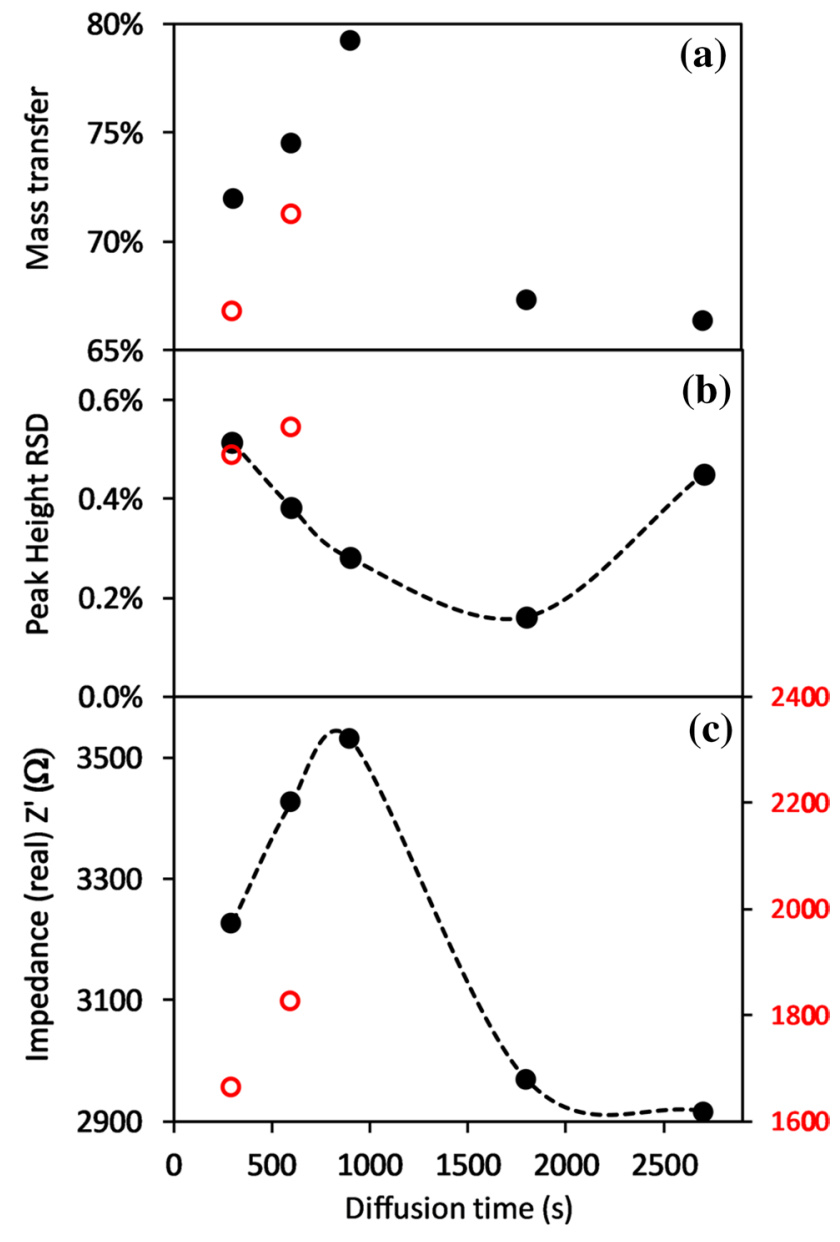

Fig. 12 a Mass transfer ratio across membrane against diffusion hold time for low (solid black, $1.6 \mu \mathrm{L} \mathrm{s}^{-1}$ ) and high (red, $12 \mu \mathrm{L} \mathrm{s}^{-1}$ ) flow conditions. b Background-subtracted Z' peak RSD and c absolute height values for $2000 \mu \mathrm{M}$ DIC. Interelectrode gap was $0.9 \mathrm{~mm}$, with $7.0 \mathrm{mM} \mathrm{NaOH}$

to $>600 \mu \mathrm{L}$ but the pulse width reduced to $\sim 50 \mathrm{~s}$. The equivalent analysis using peak areas rather than heights showed similar trends, but the RSD values were higher, with a minimum of $0.5 \%$ after 15 min diffusion.

There are several potential contributing factors to the observed precision and any given condition. Some will remain intrinsic to the microfluidic device, while others may be influenced by laboratory experimental conditions. The latter include syringe precision, bench electronics and instrumental temperature fluctuation. Ocean capable fixed volume solenoid pumps e.g. custom modified Lee LPV Series, with oil fill holes for pressure equalisation in a collapsible bag, offer sufficient precision of $0.04 \%$ of the full pump stroke for this task. For a $750 \mu \mathrm{L}$ pump, precision would be $0.3 \mu \mathrm{L}$. Modern precision laboratory syringes, e.g. Cetoni Low Pressure NeMeSys, can offer flow rates of as low as $0.6 \mathrm{~nL} / \mathrm{min}$ with a $1 \mathrm{~mL}$ syringe, suggesting these may also be sufficiently precise $(<0.1 \% \mathrm{rms}$ at $\sim 10 \mu \mathrm{L} / \mathrm{min})$. 
The electronic noise level will depend on the number of useful measurements as $\mathrm{N}^{0.5}$, which in turn depends on measurement frequency, $\mathrm{CO}_{2}$-loaded $\mathrm{NaOH}$ volume and flow rate. The dedicated C4D electronics allows sampling rates of up to $100 \mathrm{~Hz}$ at a single excitation frequency, whereas the Solartron in this set up is limited to a maximum sampling rate to $0.2 \mathrm{~Hz}$. The use of a low flow rate is limited by analyte diffusion, discussed below.

The differences in $\mathrm{C} 4 \mathrm{D}$ results here $(0.25 \%)$ compared to those reported by Bresnahan and Martz (0.1\%) for a similar measurement setup, are due primarily to the use of long $(165 \mathrm{~mm})$ tubular membranes, in the latter case, with a high surface area-to-volume ratio. They observed precision values $>0.5 \%$ for planar cell constructions but performance improved by increasing sample volume and, to a lesser degree, diffusion time. The latter determines the equilibration fraction.

Assuming similar diffusion rates for $\mathrm{CO}_{2}$ in PDMS and water, the time constant $(l=\sqrt{ } \mathrm{Dt})$ for filling a $1 \mathrm{~mm}$ deep receiver chamber is approximately $500 \mathrm{~s}$ and hence the $80 \%$ equilibration after a $900 \mathrm{~s}$ exchange diffusion time, Fig. 12 is to be expected (Merkel et al. 2000; Cadogan et al. 2014). Complete equilibration therefore requires extended diffusion times or a reduction in the chamber depth. The latter option significantly increases flow resistance and hence the achievable flow rate, for given pump capability and power, and would also limit the depth sampling resolution on a float. While longer diffusion times would increase the analyte concentration in the receiver chamber, sideways diffusion along input and output channels of the receiving chamber will widen the elution peak and increase effective losses as the edge concentrations approach a limit of detection (LOD) around $20-25 \mu \mathrm{mol} \mathrm{kg}{ }^{-1}(\sim 3 \sigma)$. Similar diffusion will also occur on the sample side, exacerbating this issue. To avoid the need for additional check valves either side of sample and receive chambers, we investigated the approach of using large chamber volumes with narrow inlet and outlet channels to minimise mass diffusion. However, increasing the chamber width or depth led to significant analyte trapping in dead zones and required greatly increased sample and reagent volumes for flushing between individual samples. We also observed, especially with wider channels, oscillatory flexing of the membrane into the receive chamber. This may set up pulsating flow or partial blockage and needs to be minimised or avoided altogether.

The use of microfluidic volume exchange and conductivity cells demonstrates the potential of the proposed approach for ocean chemical analysis. Known factors which affect results include thermal drift and stored reagent drift. On ocean probes, the first of these can be compensated for by analysing stored samples only at a fixed park depth. Reagent drift can be compensated for by performing regular calibrations, for low, high and mid-point DIC values.
There is a possible trade-off between analysis time (equilibration and measurement) and precision. In the case of the Argo system, probes are parked at depth between profiles for $\sim 10$ days, so that it may be preferred to collect samples during descent and use extended analysis times for improved precision. A full profile could collect $\sim 50$ samples, and with $\sim 180$ profiles in 5 years, at $500 \mu \mathrm{L}$ of reagent usage per sample, would require $3.5 \mathrm{~L}$ of $\mathrm{NaOH}$ and $0.1 \mathrm{~L}$ of $\mathrm{HCl}$. To reduce the reagent storage further will require commensurate reduction of the exchange and conductivity cell volumes without loss of precision. Also, to avoid inter-sample diffusion over the extended analysis period will require development of robust ultra-small non-hydraulic microvalve networks. Some applications, however, such as instruments tethered to moored buoys, or within autonomous surface vehicles, will not place such strong constraints on sample and reagent volumes, and so facilitate easier implementation.

\section{Conclusions}

Conductimetric determination of dissolved inorganic carbon concentration, in the seawater range of $1000-3000 \mu \mathrm{mol} \mathrm{kg}{ }^{-1}$, has been achieved using a microfluidic thin-film electrode conductivity cell and a membrane-based gas exchange cell. After transfer across the membrane, the eluted $\mathrm{CO}_{2}$ reacted in a $\mathrm{NaOH}$ carrier, was drawn through a conductivity cell, with $\mathrm{a}<1 \mu \mathrm{L}$ interelectrode volume, where the change in impedance versus time was measured. Minimum precision values obtained at $2000 \mu \mathrm{mol} \mathrm{kg}^{-1}$ from relative standard deviation were $\sim 0.2 \%$ from peak height and $0.5 \%$ from area under curve. This compares favourably with precision values of $\sim 0.25 \%$ obtained using a large $\mathrm{C} 4 \mathrm{D}$ electrophoresis headstage of similar active measurement volume. The required sample and reagent volumes amounted to $\sim 500 \mu \mathrm{L}$ in total due to the incorporation of a planar membrane into a small-volume exchange cell. This compares very favourably with previous attempts at conductivity-based DIC analysis where total volumes between 5000 and $10,000 \mu \mathrm{L}$ were required while achieving precision values approaching $0.1 \%$ also necessitated the use of $20 \mathrm{~cm}$ long membrane tubes and wire electrodes. The achievement here of high precision miniaturisation suggests the potential for future development of a lab-on-chip-based conductimetric analysis approach for autonomous continuous measurement of ocean chemistry via float deployment, or on other platforms and measurement equipment. Performance improvement in the near future will require addressing membrane chemical and mechanical stability as well as volume reduction and component integration into a single manifold. Continuous and autonomous ocean profiling of DIC remains an immense challenge and future success is not guaranteed. The ability to measure $\mathrm{CO}_{2}$ to the desired 
precision in a microfluidic cell, as demonstrated here, is a first proof of principle of one element of any future microfluidic profiling technology.

Acknowledgements The authors would like to acknowledge the funding support from Invest N. Ireland (RD0714186), the Department of Employment and Learning, N. Ireland (US-IRL 013), Science Foundation Ireland (09/US/I1758), and National Science Foundation (US) (NSF 0961250). We would also like to acknowledge Todd Martz and Phil Bresnahan of Scripps Institute of Oceanography, UC San Diego.

\section{Compliance with ethical standards}

Conflict of interest The authors declare that they have no conflict of interest.

Open Access This article is licensed under a Creative Commons Attribution 4.0 International License, which permits use, sharing, adaptation, distribution and reproduction in any medium or format, as long as you give appropriate credit to the original author(s) and the source, provide a link to the Creative Commons licence, and indicate if changes were made. The images or other third party material in this article are included in the article's Creative Commons licence, unless indicated otherwise in a credit line to the material. If material is not included in the article's Creative Commons licence and your intended use is not permitted by statutory regulation or exceeds the permitted use, you will need to obtain permission directly from the copyright holder. To view a copy of this licence, visit http://creativecommons.org/licenses/by/4.0/.

\section{References}

Bass AM, Bird MI, Morrison MJ, Gordon J (2012a) Continuous automated dissolved inorganic carbon analyzer with application to aquatic carbon cycle science. Limnol Oceanogr 10:10-19. https ://doi.org/10.4319/lom.2012.10.10

Bass AM, Bird MI, Munksgaard NC, Wurster CM (2012b) ISO-CADICA: isotopic - continuous, automated dissolved inorganic carbon analyser. Rapid Commun Mass Spectrom 26:639-644. https://doi. org/10.1002/rcm.6143

Bell RJ, Short RT, Byrne RH (2011) In situ determination of total dissolved inorganic carbon by underwater membrane introduction mass spectrometry. Limnol Oceanogr Methods 9:164-175. https ://doi.org/10.4319/1om.2011.9.164

Bresnahan P, Martz T (2018) Gas diffusion cell geometry for a microfluidic dissolved inorganic carbon analyzer. IEEE Sens J 6:22112217. https://doi.org/10.1109/JSEN.2018.2794882

Bresnahan P, Martz T, deAlmeida J, Ward B, Maguire PD (2017) Looking ahead: a profiling float micro-rosette. Oceanography 30:32. https://doi.org/10.5670/oceanog.2017.215

Byrne RH (2014) Measuring ocean acidification: new technology for a new era of ocean chemistry. Environ Sci Technol 48:5352-5360. https://doi.org/10.1021/es405819p

Clarke JS, Humphreys MP, Tynan E, Kitidis V, Brown I, Mowlem M, Achterberg EP (2017) Characterization of a time-domain dual lifetime referencing $\mathrm{pCO}_{2}$ optode and deployment as a high-resolution underway sensor across the high latitude north atlantic ocean. Front Marine Sci 4:396. https://doi.org/10.3389/fmars.2017.00396

Cadogan SP, Maitland GC, Trusler JPM (2014) Diffusion coefficients of $\mathrm{CO}_{2}$ and $\mathrm{N}_{2}$ in water at temperatures between $298.15 \mathrm{~K}$ and 423.15 K at pressures up to $45 \mathrm{MPa}$. J Chem Eng Data 59:519_ 525. https://doi.org/10.1021/je401008s
DeGrandpre MD, Hammar TR, Smith SP, Sayles FL (1995) In situ measurements of seawater pCO $_{2}$. Limnol Oceanogr 40:969-975. https://doi.org/10.4319/lo.1995.40.5.0969

Dickson AG, Sabine CL, Christian JR (2007) Guide to best practices for ocean CO2 measurements. PICES Special Publication 3. North Pacific Marine Science Organization, Canada

Dlugokencky E, Tans P (2019) Trends in atmospheric carbon dioxide earth system research laboratory. www.esrl.noaa.gov/gmd/ ccgg/trends/. Accessed 17 June 2019

Fassbender AJ, Sabine CL, Lawrence-Slavas N, De Carlo EH, Meinig C, Maenner Jones S (2015) Robust sensor for extended autonomous measurements of surface ocean dissolved inorganic carbon. Environ Sci Technol 49:3628-3635. https://doi. org/10.1021/es5047183

Freije-Carrelo L, Sobrado LA, Moldovan M, Encinar JR, Alonso JIG (2018) Isotope dilution mass spectrometry for highly precise determination of dissolved inorganic carbon in seawater aiming at climate change studies. Anal Chem 90:4677-4685. https:// doi.org/10.1021/acs.analchem.7b05242

Gorry PA (1991) General least-squares smoothing and differentiation of nonuniformly spaced data by the convolution method. Anal Chem 63:534-536. https://doi.org/10.1021/ac00005a031

Guéguen C, Tortell PD (2008) High resolution measurement of Southern Ocean $\mathrm{CO}_{2}$ and $\mathrm{O}_{2} / \mathrm{Ar}$ by membrane inlet mass spectrometry. Mar Chem 108:184-194. https://doi.org/10.1016/j. marchem.2007.11.007

Hall PJ, Aller RC (1992) Rapid, small-volume, flow injection analysis for $\mathrm{SCO}_{2}$, and $\mathrm{NH}^{4+}$ in marine and freshwaters. Limnol Oceanogr 37:1113-1119. https://doi.org/10.4319/ lo.1992.37.5.1113

Hansen T, Gardeler B, Matthiessen B (2013) Technical Note: Precise quantitative measurements of total dissolved inorganic carbon from small amounts of seawater using a gas chromatographic system. Biogeosciences 10:6601-6608. https://doi.org/10.5194/ bg-10-6601-2013

Henríquez C, Horstkotte B, Cerdà V (2014) A highly reproducible solenoid micropump system for the analysis of total inorganic carbon and ammonium using gas-diffusion with conductimetric detection. Talanta 118:186-194. https://doi.org/10.1016/j.talan ta.2013.10.005

Hoherčáková Z, Opekar F (2005) A contactless conductivity detection cell for flow injection analysis: determination of total inorganic carbon. Anal Chim Acta 551:132-136. https://doi.org/10.1016/j. aca.2005.07.029

Kaltin S, Haraldsson C, Anderson LG (2005) A rapid method for determination of total dissolved inorganic carbon in seawater with high accuracy and precision. Mar Chem 96:53-60. https://doi. org/10.1016/j.marchem.2004.10.005

Liu X, Byrne RH, Adornato L, Yates KK, Kaltenbacher E, Ding X, Yang B (2013) In situ spectrophotometric measurement of dissolved inorganic carbon in seawater. Environ Sci Technol 47:11106-11114. https://doi.org/10.1021/es4014807

Merkel TC, Bondar VI, Nagai K, Freeman BD, Pinnau I (2000) Gas sorption, diffusion, and permeation in poly(dimethylsiloxane). J Polym Sci Part B 38:415-434. https://doi.org/10.1002/ (SICI) 1099-0488(20000 201)38:3\%3c415:AID-POLB 8 \%3e3.0.CO;2-Z

Millero FJ (2007) The marine inorganic carbon cycle. Chem Rev 107:308-341. https://doi.org/10.1021/cr0503557

Nakano Y, Kimoto H, Watanabe S, Harada K, Watanabe YW (2006) Simultaneous vertical measurements of in situ $\mathrm{pH}$ and $\mathrm{CO}_{2}$ in the sea using spectrophotometric profilers. J Oceanogr 62:71-81

Plant JN, Johnson KS, Needoba JA, Coletti LJ (2009) NH4-Digiscan: an in situ and laboratory ammonium analyzer for estuarine, coastal, and shelf waters. Limnol Oceanogr 7:144-156. https:// doi.org/10.4319/lom.2009.7.144 
Roemmich D, Johnson GC, Riser S, Davis R, Gilson J, Owens WB, Garzoli SL, Schmid C, Ignaszewski M (2009) The Argo program: observing the global ocean with profiling floats. Oceanography 22(2):34-43. https://doi.org/10.5670/oceanog.2009.36

Rérolle VMC, Achterberg EP, Ribas-Ribas M, Kitidis V, Brown I, Bakker DCE, Lee GA, Mowlem MC (2018) High resolution pH measurements using a lab-on-chip sensor in surface waters of Northwest European Shelf Seas. Sensors 18:2622. https://doi. org/10.3390/s18082622

Sabine CL, Feely RA, Gruber N, Key RM, Lee K, Bullister JL, Wanninkhof R, Wong CS, Wallace DWR, Tilbrook B, Millero FJ, Peng T, Kozyr A, Ono T, Rios AF (2004) The oceanic sink for anthropogenic $\mathrm{CO}_{2}$. Science 305:367-371. https://doi.org/10.1126/scien ce. 1097403

Sayles FL, Eck C (2009) An autonomous instrument for time series analysis of $\mathrm{TCO}_{2}$ from oceanographic moorings. Deep-Sea Res Part I Oceanogr Res Pap 56:1590-1603. https://doi.org/10.1016/j. dsr.2009.04.006

Sun D, Tweedie M, Gajula DR, Ward B, Maguire PD (2015) Highstrength thermoplastic bonding for multi-channel, multi-layer lab-on-chip devices for ocean and environmental applications. Microfluid Nanofluid 19:913-922

Tortell PD (2005) Dissolved gas measurements in oceanic waters made by membrane inlet mass spectrometry. Limnol Oceanogr 3:24-37. https://doi.org/10.4319/lom.2005.3.24

Tweedie M, Sun D, Ward B, Maguire PD (2019) Long-term hydrolytically stable bond formation for future membrane-based deep ocean microfluidic chemical sensors. Lab Chip 19:1287-1295. https://doi.org/10.1039/C9LC00123A

Tweedie M, Macquart A, Almeida J, Ward B, Maguire P (2020) Metered reagent injection into microfluidic continuous flow sampling for conductimetric ocean dissolved inorganic carbon sensing. Meas Sci Technol 31:065104. https://doi.org/10.1088/13616501/ab7405

Wang ZA, Liu X, Byrne RH, Wanninkhof R, Bernstein RE, Kaltenbacher EA, Patten J (2007) Simultaneous spectrophotometric flow-through measurements of $\mathrm{pH}$, carbon dioxide fugacity, and total inorganic carbon in seawater. Anal Chim Acta 596:23-36. https://doi.org/10.1016/j.aca.2007.05.048

Wang ZA, Chu SN, Hoering KA (2013) High-frequency spectrophotometric measurements of total dissolved inorganic carbon in seawater. Environ Sci Technol 2013(47):7840-7847. https://doi. org/10.1021/es400567k

Wang ZA, Sonnichsen FN, Bradley AM, Hoering KA, Lanagan TM, Chu SN, Hammar TR, Camilli R (2015) In situ sensor technology for simultaneous spectrophotometric measurements of seawater total dissolved inorganic carbon and $\mathrm{pH}$. Environ Sci Technol 49:4441-4449. https://doi.org/10.1021/es504893n

Publisher's Note Springer Nature remains neutral with regard to jurisdictional claims in published maps and institutional affiliations. 